\title{
Platelet-to-lymphocyte ratio (PLR) and Plateletcrit (PCT) in young patients with morbid obesity
}

\author{
Emrah Erdal \\ Mehmet Inanir ${ }^{1}$
}

1. Specialist Bolu Abant İzzet Baysal University, Medical Faculty, Department of Cardiology, Bolu, Turkey.

\section{SUMMARY}

OBJECTIVE: To compare the complete blood counts, namely the plateletcrit (PCT) and Platelet-To-Lymphocyte Ratio (PLR) of healthy subjects and those with morbid obesity in the young population.

METHODS: We included 45 patients with morbid obesity (body mass index -BMl - greater than or equal to $45 \mathrm{~kg} / \mathrm{m2}$ ) and 45 healthy subjects (BMI less than or equal to $25 \mathrm{~kg} / \mathrm{m} 2$ ) in our study. Blood samples were obtained from the participants following a 12-hour fasting period. Then we evaluated the levels of hemoglobin $(\mathrm{Hb})$, hematocrit $(\mathrm{HCT})$, red cell distribution width (RDW), mean platelet volume (MPV), white blood cell (WBC), PLR, platelet counts, and PCT in the complete blood count.

RESULTS: The morbid obesity group had significantly higher platelet counts and PCT values ( $p<0.001)$, and PLR values ( $p=0.033$ ). The value of WBC was also higher in the obese group $(p=0.001)$. MPV was lower in the obesity group but not statistically significant ( $p=0.815$ ). No significant difference was found between hemoglobin and hematocrit values in these groups; but RDW valuewere higher and statistically significant in the obese group $(p=0.001)$.

CONCLUSION: PLR or PCT may be more useful as a marker in determining an increased thrombotic state and inflammatory response in morbid obesity.

KEYWORDS: Obesity, Morbid. Blood Platelets. Lymphocytes.

\section{INTRODUCTION}

Obesity is one of the most common health conditions and its incidence has recently increased, almost escalating to a real epidemic. ${ }^{1}$ It is a risk factor for cardiovascular diseases, including angina pectoris, hypertension, congestive heart failure, myocardial infarction, and atrial fibrillation. ${ }^{2}$

Obesity is defined as an excessive or unhealthy buildup of fat and is most likely to have an adverse ef- fect on health. According to the classification by the World Health Organization (WHO) for overweight and obesity based on body mass index (BMI), obesity is defined as a BMI greater than or equal to $30.0 \mathrm{~kg} /$ $\mathrm{m} 2$, and it is classified as morbid when the BMI is greater than or equal to $40 \mathrm{~kg} / \mathrm{m} 2 .^{3}$

Hypertrophy and hyperplasia of fatty tissue give rise to hypoxia in adipocytes, thus increasing the lev- 
el of stress in cells. Consequently, local pro-inflammatory substances are released, leading to inflammation. ${ }^{4}$ Inflammation accelerates the development of atherosclerosis and may also induce atherosclerotic plaque rupture and thrombosis. ${ }^{5}$

Complete Blood Count (CBC) is an inexpensive yet simple and easy test to perform. Researchers have studied the effect of platelet indices including platelet count, platelet distribution width (PDW), plateletcrit (PCT), and mean platelet volume (MPV) on the diagnosis, treatment, and follow-up of various conditions. Additionally, a CBC test can be used to evaluate white blood cell (WBC), red cell distribution (RDW), neutrophil-to-lymphocyte ratio (NLR), and platelet-to-lymphocyte ratio (PLR), all of which may give insight into an inflammation. ${ }^{6}$ PLR is calculated by dividing the platelet count by the lymphocytes.

Platelets have an important effect on inflammation, thrombosis, and atherogenesis. ${ }^{7}$ Previous studies have demonstrated increased platelet counts in cardiovascular diseases and vascular complications. ${ }^{8}$ Likewise, as an indicator of platelet activation, mean platelet volume (MPV) has been shown to increase in acute myocardial infarction. ${ }^{9}$

Platelet lymphocyte ratio (PLR) has been identified as a biomarker of inflammation and proved to be significant in prognosis. ${ }^{10}$ Some studies have shown a relationship between poor prognosis and low lymphocyte count and high platelet count in acute coronary syndrome. Additionally, PLR's effect on mortality it has been shown to be independent of platelet or lymphocyte counts. ${ }^{11}$

Similarly, a correlation has been found between PLR and adverse outcomes in various cardiac pathologies. ${ }^{12}$

Some of the results were not consistent with recent studies on platelet counts and MPV for individuals with obesity. The calculation of PCT, which gives better information on total platelet mass, is done according to the following formula: PCT = Platelet count $\mathrm{x}$ MPV / 10,000. By comparing BMI with whole blood parameters in their study, Furuncuoğlu et al. ${ }^{13}$ demonstrated that MPV was not statistically significant; however, they found a statistically significant positive correlation between BMI and PCT. To this respect, PCT and PLR values can provide us with more accurate insight into inflammation as well as increased thrombogenic activities. ${ }^{14}$

In this paper, we aim to compare the complete blood counts, namely the PCT and PLR values, of healthy subjects with those of morbid obese individuals in the young population.

\section{METHODS}

\section{Study population}

The present cross-sectional study was conducted at Bolu Abant Izzet Baysal University Hospital between March 2018 and October 2018. The local Ethics Committee approved the study protocol. Following the exclusion procedure, we included 45 patients with morbid obesity (BMI greater than or equal to $45 \mathrm{~kg} / \mathrm{m} 2$ ) and 45 healthy subjects (BMI value less than or equal to $25 \mathrm{~kg} / \mathrm{m} 2$ ) in our study. The mean ages were $33 \pm 7$ and $33 \pm 5$ years for the obesity group and the healthy group, respectively. We did not include patients older than 45 years because of the high likelihood of unknown atherosclerosis and comorbidities, both of which could have affected the parameters of complete blood count. Exclusion criteria also included chronic diseases such as chronic renal failure, hypo/hyperthyroidism, coronary artery disease, any hematological abnormality, and medication such as antiplatelet agent and steroid use due to their ability to change the results of a complete blood count. In addition, pregnant women, and patients with anemia and vitamin deficiency (i.e., vitamins D and B12) were excluded from the study. Blood samples were obtained from the participants following a 12-hour fasting period. We then evaluated the levels of hemoglobin (Hb), hematocrit (HCT), PDW, RDW, MPV, WBC, PLR, platelet counts, and plateletcrit (PCT) in the complete blood count.

\section{Statistical analysis}

We carried out analyses using SPSS 18.0 Statistical Package Software for Windows Operating System (SPSS Inc, Chicago, Illinois, USA). Quantitative and qualitative variables were expressed as mean \pm standard deviation (SD), and numbers and percentages, respectively. In order to assess the differences between these groups, we used the Student t-test for normally distributed variables, the Mann-Whitney's U-test for variables without normal distribution, and the Chi-square test for qualitative variables. The correlations of MPV, WBC, PCT, RDW, PLR, and PLT were assessed using the Pearson correlation analyses. We used multivariate linear regression to analyze the value of different baseline characteristics as independent predictors of morbid obesity. ROC 
(receiver operating characteristic) curves were used to evaluate the diagnostic ability of PCT and PLR to detect morbid obesity. All results at $\mathrm{p} \leq 0.05$ were considered statistically significant.

FIGURE 1. ROC CURVE ANALYSIS OF PCT AND PLR FOR PREDICTION OF MORBID OBESITY. AT THE CUT-OFF VALUE OF > 0.203, SENSITIVITY AND SPECIFICITY OF PCT WERE 80\% AND 67\%, RESPECTIVELY (AUC = 0.775, 95\% Cl,0.678-0.871). AT THE CUT-OFF VALUE OF $>108$ MMHG, SENSITIVITY AND SPECIFICITY OF PLR WERE 68\% AND 54\%, RESPECTIVELY (AUC = 0.620, 95\% Cl,0.504-0.736). AUC: AREA UNDER THE CURVE, CI: CONFIDENCE INTERVAL, PCT: PLATELETCRIT, PLR: PLATELET-TO-LYMPHOCYTE RATIO

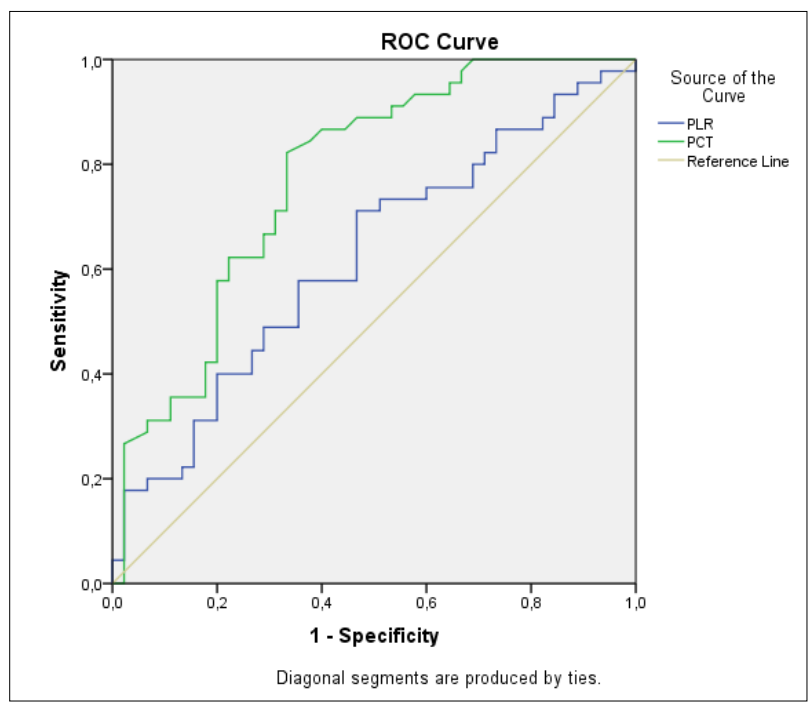

\section{RESULTS}

There was no significant difference between study patients and the control group regarding the frequencies of diabetes mellitus, hypertension, smoking, and hyperlipidemia (Table 1). The morbid obesity group had significantly higher platelet counts, PCT values $(p<0.001)$, and PLR values $(\mathrm{p}=0.033)$ (Table 2$)$. ROC curve analysis was performed to evaluate PCT and PLR in order to predict morbid obesity. At the cutoff value of $>0,203$, the sensitivity and specificity of PCT were $80 \%$ and $67 \%$, respectively. At the cut-off value of $>108 \mathrm{mmHg}$, the sensitivity and specificity of PLR were $68 \%$ and $54 \%$, respectively (Figure 1 ).

No significant difference was found between hemoglobin and hematocrit values in these groups, but $\mathrm{RDW}$ values were higher in the obese group and were statistically significant $(\mathrm{p}=0.001)$. Likewise, the value of WBC was higher in the obese group $(\mathrm{p}=0.001)$. PCT, PLR, RDW, and WBC distribution in the obesity and healthy groups are shown in Figure-2. MPV was lower in the obesity group but not statistically significant $(\mathrm{p}=0.815)$.

\section{DISCUSSION}

In this study, we compared CBC parameters between morbidly obese patients and healthy subjects

FIGURE 2. PCT, PLR, RDW AND WBC DISTRIBUITION OF HEALTHY AND OBESITY GROUP
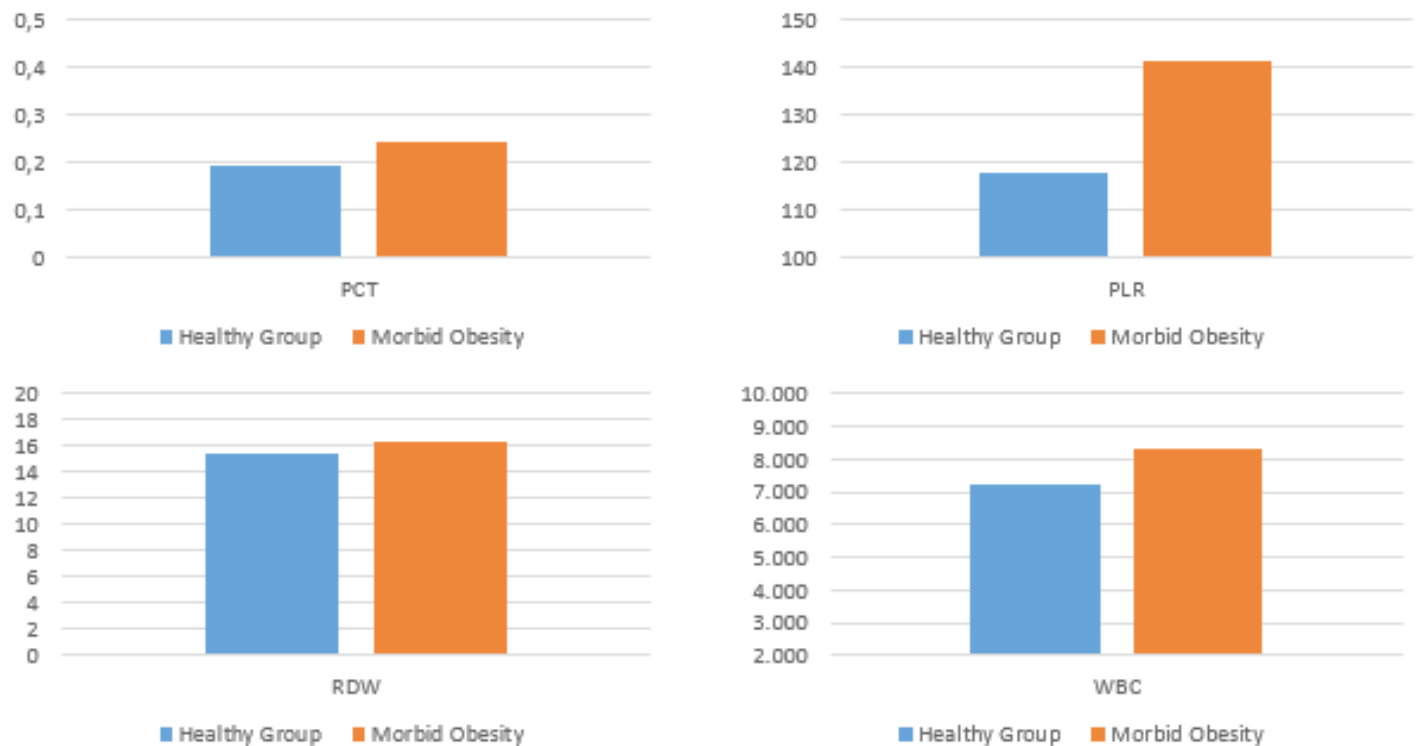
TABLE 1. GENERAL CHARACTERISTICS OF THE STUDY GROUPS

\begin{tabular}{|c|c|c|c|}
\hline Baseline characteristics & Healthy group $(n=45)$ & Obesity group $=45$ & $p$ \\
\hline Age (mean $\pm S D)$ (years)) & $33 \pm 5$ & $33 \pm 7$ & 0.421 \\
\hline Male/female & $29 / 16$ & $34 / 11$ & 0.25 \\
\hline Hypertension(\%) & $4(9 \%)$ & $5(11 \%)$ & 0.235 \\
\hline Smoking & $11(24 \%)$ & $9(20 \%)$ & 0.162 \\
\hline Diabetes mellitus & $3(7 \%)$ & $4(9 \%)$ & 0.173 \\
\hline Hyperlipidemia & $2(4 \%)$ & $3(6 \%)$ & 0.317 \\
\hline $\mathrm{BMI}$ & $19.4 \pm 1.5$ & $46.0 \pm 6.5$ & 0.000 \\
\hline
\end{tabular}

BMI: body mass index, SD: standard deviation

TABLE 2. LABORATORY DATA OF THE STUDY COHORT

\begin{tabular}{|c|c|c|c|}
\hline & Healthy group $(n=45)$ & Obesity group $=45$ & $\mathrm{p}$ \\
\hline Creatinine (mg/dl) & $0.75 \pm 0.168$ & $0.7 \pm 0.108$ & 0.178 \\
\hline Fasting plasma glucose (mg/dl) & $88 \pm 11$ & $91 \pm 12$ & 0.235 \\
\hline LDL-cholesterol (mg/dl) & $88.44 \pm 34$ & $114,35 \pm 44$ & 0.001 \\
\hline HDL-cholesterol (mg/dl) & $58 \pm 15$ & $45 \pm 9$ & 0.000 \\
\hline Triglyceride (mg/dl) & $74 \pm 32$ & $125 \pm 59$ & 0.000 \\
\hline Total cholesterol (mg/dl) & $160 \pm 41$ & $185 \pm 47$ & 0.002 \\
\hline Hemoglobin (gr/dl) & $13.6 \pm 1.9$ & $13.2 \pm 1.8$ & 0.141 \\
\hline Hematocrit (\%) & $40.41 \pm 5.3$ & $40.55 \pm 4.9$ & 0.945 \\
\hline MPW(fl) & $8.4 \pm 1.52$ & $8.38 \pm 1.45$ & 0.815 \\
\hline Platelet counts $(\mathrm{k} / \mathrm{mm} 3)$ & $235 \pm 74$ & $298 \pm 74$ & 0.000 \\
\hline PDW & $17 \pm 1.5$ & $17.6 \pm 1.3$ & 0.127 \\
\hline RDW & $15.4 \pm 2.3$ & $16.3 \pm 1.6$ & 0.001 \\
\hline PCT & $0.192 \pm 0.056$ & $0.244 \pm 0.051$ & 0.000 \\
\hline PLR & $118 \pm 44$ & $141 \pm 56$ & 0.033 \\
\hline NLR & $2.1 \pm 0.8$ & $2.5 \pm 1.2$ & 0.132 \\
\hline WBC (x10 3ul) & $7.2 \pm 1.89$ & $8.3 \pm 1.97$ & 0.001 \\
\hline
\end{tabular}

HDL: high-density lipoprotein, LDL: low-density lipoprotein, MPV: mean platelet volume, NLR: neutrophil-to-lymphocyte ratio, PCT: Plateletcrit, PDW: platelet distribution width, PLR: platelet-to-lymphocyte ratio RDW: Red cell distribution width, platelet distribution width, WBC: white blood cell

in the young population. According to our results; platelet counts, PCT, and PLR values were significantly higher in the morbid obesity group. We found that RDW values were significantly higher in the obesity group, and there was no significant difference between hemoglobin and hematocrit values in these groups.

As a chronic inflammation, obesity is associated with an increased atherothrombotic process. ${ }^{15,16} \mathrm{~A}$ positive correlation between cardiovascular disease and inflammatory markers has been shown in recent epidemiological studies. ${ }^{5}$

Previous studies have shown that RDW can be used in the prognosis of cardiovascular diseases and heart failure. ${ }^{17}$ Increased RDW is an important predictor of mortality and morbidity in atherosclerotic disease and heart failure, regardless of hemoglo- bin level. ${ }^{18}$ Vayá et al. ${ }^{19}$ have shown that RDW values were significantly higher in the obesity group; however, hemoglobin was lower in morbidly obese patients. Therefore, they concluded that increased levels of RDW were due to other causes rather than inflammation.

In the obesity group of our study, platelet counts were significantly higher compared to healthy individuals $(p<0.001)$, but MPV values were not different in both groups. In another study, MPV values were significantly higher in the obesity group than those in the non-obese group; however, there was no significant difference in platelet counts between these groups. ${ }^{20}$ Contrarily, Farhangi et al. ${ }^{21}$ reported that the difference for MCV values between the obesity and the healthy groups was not significant, and they found the platelet count to be significantly higher 
in the obesity group $(\mathrm{p}=0.047)$. Another study has shown that MPV values decrease significantly after weight loss. ${ }^{22}$

In various studies, researchers investigated the correlation between MPV and platelet count along with weight loss after bariatric surgery. They have found platelet counts to decrease significantly $(p=0.0015)$, but there was no significant decrease in MPV $(\mathrm{p}=0.34)^{23}$ Kutluturk and Ozsoy ${ }^{24}$ reported a significant decrease in platelet counts and a significant increase in MPV after sleeve gastrectomy.

The study results above are different and contradictory regarding MPV and platelet counts. In our opinion, PCT values may provide us with more accurate insight into platelet mass and their functions. PLR may also give more important information about an increased inflammatory status compared to platelet or lymphocyte count alone.

We reported that PLR was significantly higher in the obese group $(p=0,033)$. In several previous clinical trials in which PLR was compared in obese individuals, no statistically significant difference was found between PLR and BMI. ${ }^{13}$ Recent studies have demonstrated that plateletcrit can provide more detailed and accurate information about platelet activation. Han et al..$^{25}$ reported a positive relationship between PCT values, platelet counts, and body fat; however, they found no significant correlations between the other platelet indices including PDW, MPV, and body fat mass in their study. Likewise, Furuncuglu et al. ${ }^{13}$ found a statistically significant positive relationship between PCT and BMI.

We examined PCT values from whole blood count and found that they were significantly higher in the obesity group $(p<0.001)$. Our results are also consistent with those of other recent studies. To the best of our knowledge, this is thus far the only study in the literature conducted on young morbid obese patients and the first clinical study demonstrating that PLR is significantly higher in patients with morbid obesity.

\section{CONCLUSION}

PLR or PCT may be more useful as a marker in determining an increased thrombotic state and inflammatory response in morbidly obese patients. We need to support our findings with larger, prospective, and randomized studies.

\section{Authors' contributions}

Concept, study design, and project management were done by Dr. Erdal; statistics and writing were done by Dr. Inanir.

\section{RESUMO}

OBJETIVO: Comparar as contagens sanguíneas completas, nomeadamente o plateletcrit (PCT) e a razão plaquetas/linfócitos (PPL) de indivíduos saudáveis com aqueles que têm obesidade mórbida na população jovem.

MÉTODOS: Incluímos 45 pacientes com obesidade mórbida (índice de massa corporal superior a $45 \mathrm{~kg} / \mathrm{m} 2$ ) e 45 indivíduos saudáveis (índice de massa corporal inferior a $25 \mathrm{~kg} / \mathrm{m} 2$ ) em nosso estudo. Foram obtidas amostras de sangue dos participantes após um período de jejum de 12 horas. Depois, avaliamos os níveis de hemoglobina, hematócrito, largura de distribuição dos glóbulos vermelhos, volume médio de plaquetas, glóbulos brancos, razão plaquetas/linfócitos, contagem de plaquetas e plateletcrit no hemograma completo.

RESULTADOS: O grupo de obesidade mórbida teve contagens plaquetárias e valores plateletcrit significativamente mais elevados ( $p<0$, 001), e valores razão plaquetas/linfócitos ( $p=0,033)$. O valor dos glóbulos brancos também foi maior no grupo obeso ( $p=0,001)$. 0 volume médio dos plateletes foi inferior no grupo da obesidade, mas não estatisticamente significativo ( $p=0,815)$. Não foi encontrada diferença significativa entre os valores de hemoglobina e hematócrito nesses grupos, mas os valores da largura de distribuição dos glóbulos vermelhos foram mais elevados no grupo obeso e estatisticamente significativos ( $p=0,001)$.

CONCLUSÃo: Relação plaquetas-linfócitos e valores de plateletcrit podem ser mais úteis como marcadores na determinação de um estado trombótico aumentado e da resposta inflamatória na obesidade mórbida.

PALAVRAS-CHAVE: Obesidade mórbida. Plaquetas. Linfócitos.

\section{REFERENCES}

1. Khan SS, Ning H, Wilkins IT, Allen N, Carnethon M, Berry JD, et al. Association of body mass index with lifetime risk of cardiovascular disease and compression of morbidity. JAMA Cardiol. 2018;3(4):280-7.

2. Pi-Sunyer $X$. The medical risks of obesity. Postgrad Med. 2009;121(6):21-33.

3. National Institutes of Health. Clinical guidelines on the identification, evaluation, and treatment of overweight and obesity in adults-the evidence report. Obes Res. 1998;6(Suppl 2):51S-209S.

4. Cousin B, Munoz O, André M, Fontanilles A, Dani C, Cousin I, et al. A role for preadipocytes as macrophage-like cells. FASEB J. 1999;13(2):305-12.

5. Sabatine MS, Morrow DA, Cannon CP, Murphy SA, Demopoulos LA, 
DiBattiste PM, et al. Relationship between baseline white blood cell count and degree of coronary artery disease and mortality in patients with acute coronary syndromes: a TACTICS-TIMI 18 (Treat Angina with Aggrastat and determine Cost of Therapy with an Invasive or Conservative StrategyThrombolysis in Myocardial Infarction 18 trial) substudy. I Am Coll Cardiol. 2002;40(10):1761-8.

6. Sahin F, Yildiz P. Serum platelet, MPV, PCT and PDW values, neutrophi to lymphocyte and platelet to lymphocyte ratios in lung cancer diagnosis. Eur Respir ). 2015;46(suppl 59):PA4279.

7. Gawaz M, Langer $H$, May AE. Platelets in inflammation and atherogenesis J Clin Invest. 2005;115(12):3378-84.

8. Schneider DJ. Factors contributing to increased platelet reactivity in people with diabetes. Diabetes Care. 2009;32(4):525-7.

9. Park Y, Schoene N, Harris W. Mean platelet volume as an indicator of platelet activation: methodological issues. Platelets. 2002;13(5-6):301-6.

10. Gunaldi M, Goksu S, Erdem D, Gunduz S, Okuturlar Y, Tiken E, et al. Prognostic impact of platelet/lymphocyte and neutrophil/lymphocyte ratios in patients with gastric cancer: a multicenter study. Int J Clin Exp Med. 2015;8(4):5937-42

11. Kurtul A, Murat SN, Yarlioglues M, Duran M, Ergun G, Acikgoz SK, et al. Association of platelet-to-lymphocyte ratio with severity and complexity of coronary artery disease in patients with acute coronary syndromes. Am | Cardiol. 2014;114(7):972-8.

12. Akboga MK, Canpolat U, Balci KG, Akyel A, Sen F, Yayla C, et al. Increased platelet to lymphocyte ratio is related to slow coronary flow. Angiology. 2016;67(1):21-6

13. Furuncuoğlu Y, Tulgar S, Dogan AN, Cakar S, Tulgar YK, Cakiroglu B. How obesity affects the neutrophil/lymphocyte and platelet/lymphocyte ratio, systemic immune-inflammatory index and platelet indices: a retrospective study. Eur Rev Med Pharmacol Sci. 2016;20(7):1300-6.

14. Yayla Ç, Akboğa MK, Canpolat U, Akyel A, Yayla KG, Doğan M, et al. Platelet to lymphocyte ratio can be a predictor of infarct-related artery patency in patients with ST-segment elevation myocardial infarction. Angiology. 2015;66(9):831-6
15. Eckel RH, Krauss RM. American Heart Association call to action: obesity as a major risk factor for coronary heart disease. AHA Nutrition Committee. Circulation. 1998;97(21):2099-100.

16. Li $\mathrm{N}, \mathrm{Hu} H$, Lindqvist M, Wikström-Jonsson E, Goodall AH, Hjemdahl P. Platelet-leukocyte cross talk in whole blood. Arterioscler Thromb Vasc Biol. 2000;20(12):2702-8.

17. Gürel OM, Demircelik MB, Bilgic MA, Yilmaz H, Yilmaz OC, Cakmak M, et al. Association between red blood cell distribution width and coronary artery calcification in patients undergoing 64-multidetector computed tomography. Korean Circ ). 2015;45(5):372-7.

18. van Kimmenade RR, Mohammed $A A$, Uthamalingam $S$, van der Meer $P$, Felker GM, Januzzi Jr JL. Red blood cell distribution width and 10year mortality in acute heart failure. Eur | Heart Fail. 2010;12(2):129-36.

19. Vayá A, Alis R, Hernandez-Mijares A, Solá E, Cámara R, Rivera L, et al. Red blood cell distribution width is not related with inflammatory parameters in morbidly obese patients. Clin Biochem. 2014;47(6):464-6.

20. Coban E, Ozdogan M, Yazicioglu G, Akcit F. The mean platelet volume in patients with obesity. Int J Clin Pract. 2005;59(8):981-2.

21. Farhangi MA, Keshavarz SA, Eshraghian M, Ostadrahimi A, Saboor-Yaraghi AA. White blood cell count in women: relation to inflammatory biomarkers, haematological profiles, visceral adiposity, and other cardiovascular risk factors. J Health Popul Nutr. 2013;31(1):58-64.

22. Toplak H, Wascher TC. Influence of weight reduction on platelet volume: different effects of a hypocaloric diet and a very low calorie diet. Eur | Clin Invest. 1994;24(11):778-80.

23. Raoux L, Moszkowicz D, Vychnevskaia K, Poghosyan T, Beauchet $A$, Clauser $\mathrm{S}$, et al. Effect of bariatric surgery-induced weight loss on platelet count and mean platelet volume: a 12-month follow-up study. Obes Surg. 2017;27(2):387-93.

24. Kutluturk F, Ozsoy Z. Effect of sleeve gastrectomy on platelet counts and mean platelet volumes. Obes Surg. 2018;28(10):3159-64.

25. Han S, Gan D, Wang G, Ru Y, Huang C, Lin I, et al. Associations of platelet indices with body fat mass and fat distribution. Obesity. 2018;26(10):1637-43. 